\title{
MISKONSEPSI SISWA PADA MATERI GEOMETRI DI TINGKAT SEKOLAH MENENGAH PERTAMA
}

\author{
Nelly Fitriani ${ }^{1}$, Euis Eti Rohaeti ${ }^{2}$ \\ 1,2 IKIP Siliwangi Bandung, Jl. Terusan Jenderal Sudirman, Cimahi, Indonesia \\ Email: nhe.fitriani@gmail.com
}

\begin{abstract}
This research aims to determine the types of misconceptions experienced by junior high school students in learning the concept of geometry, analyzing what is the cause, and knowing the level of geometry of students who are experiencing misconceptions. His research methods use qualitative descriptive research. The research subject is SMP Grade 9 students. The instruments used are diagnostic tests, Van Hiele geometry tests, interview guidelines. The interview is conducted to determine what kind of misconception the student is experiencing, as well as the teaching book used to determine the possible causes of the students to experience misconceptions on these materials. To determine what kind of misconception the student experienced, diagnostic test data was analyzed, and then to determine the likelihood of the students experiencing misconceptions, the data of the interviews and teaching books used were analyzed. The resulting misconception is a classifying misconception, a correlational misconception and a theoretical misconception. After learning the types of misconceptions, the students were analyzed by the geometry level Van Hiele. Five students experienced misconceptions and they were at level 1 based on the geometric levels of Van Hiele. Conclusions gained, that the students who are experiencing misconceptions are students whose geometry levels of Van Hielenya are below.
\end{abstract}

Keywords: Misconceptions, geometry level van hiele, diagnostic tests

\begin{abstract}
ABSTRAK
Penelitian ini bertujuan untuk mengetahui jenis-jenis miskonsepsi yang dialami oleh siswa SMP dalam mempelajari konsep geometri, menganalisis apa yang menjadi penyebabnya, dan mengetahui sejauhmana level geometri siswa yang mengalami miskonsepsi. Metode penelitiannya menggunakan penelitian deskriptif kualitatif. Subjek penelitian yaitu siswa SMP Kelas 9. Instrumen yang digunakan yaitu tes diagnostik, tes geometri Van Hiele, pedoman wawancara. Pelaksanaan wawancara dilakukan untuk mengetahui jenis miskonsepsi apa saja yang dialami oleh siswa, serta buku ajar yang digunakan untuk mengetahui berbagai kemungkinan penyebab siswa mengalami miskonsepsi pada materimateri tersebut. Untuk mengetahui jenis miskonsepsi apa saja yang dialami oleh siswa, data hasil tes diagnostik dianalisis, kemudian untuk mengetahui kemungkinan penyebab siswa mengalami miskonsepsi, data hasil wawancara dan buku ajar yang digunakan dianalisis. Miskonsepsi yang dihasilkan yaitu miskonsepsi klasifikasional, miskonsepsi korelasional dan miskonsepsi teoritikal. Setelah mengetahui jenis-jenis miskonsepsi yang diterjadi pada siswa, selanjutnya dianalisis level kemampuan geometrinya berdasarkan level geometri Van Hiele. Lima orang siswa mengalami miskonsepsi dan mereka berada pada level 1 berdasarkan level geometri Van Hiele. Kesimpulan yang diperoleh, bahwa siswa yang mengalami miskonsepsi merupakan siswa yang level geometri Van Hielenya berada di bawah.
\end{abstract}

Kata kunci: Miskonsepsi, level geometri van hiele, tes diagnostik

Dikirim: 28 Januari 2020; Diterima: 15 Februari 2020; Dipublikasikan: 30 Maret 2020

Cara sitasi: Fitriani, N., \& Rohaeti, E. E. (2020). Miskonsepsi siswa pada materi geometri di tingkat sekolah menengah pertama. Teorema: Teori dan Riset Matematika, 5(1), 9-16. 


\section{PENDAHULUAN}

Peneliti merupakan dosen pengajar mata kuliah Konsep Esensial Matematika SMP, memiliki pengalaman dan interaksi terus-menerus dengan mahasiswa calon guru matematika, khususnya membahas penguasaan siswa terhadap konsep geometri sekolah menengah saat ini menghasilkan sebuah keprihatinan. Kemudian, sebagian besar siswa masih menganggap bahwa matematika merupakan mata pelajaran yang sulit (Kusuma, 2019). Berdasarkan hal tersebut, menjadi sesuatu yang penting untuk mengetahui jenis kesalahan-kesalahan atau miskonsepsi yang terjadi pada siswa agar mereka dapat belajar lebih efektif di kelas. Berdasarkan latar belakang ini, peneliti ingin mengidentifikasi jenis kesalahan yang dihasilkan siswa SMP dan menyelidiki kemungkinan penyebab kesalahan untuk menyarankan langkah-langkah perbaikan kedepannya.

Menurut Ojose miskonsepsi bersumber dari kesalahan dalam memahami konsep atau kesalahan dalam mengintrepertasikan konsep (Ay, 2017). Bentuk miskonsepsi yang dialami oleh siswa ketika menyelesaikan soal terbagi menjadi 3, yaitu miskonsepsi teoritikal, miskonsepsi korelasional, dan miskonsepsi klasifikasional (Dayanti \& Nursangaji, 2019). Miskonsepsi klasifikasional diantaranya adalah kesalahan dalam menentukan unsur-unsur yang terdapat pada bangun datar (menentukan tinggi pada segitiga dan jajargenjang) ataupun bangun ruang (diagonal bidang dan bidang diagonal). Miskonsepsi korelasional meliputi kesalahan dalam menentukan hubungan antara konsep prisma dengan konsep kubus, balok, maupun tabung. Miskonsepsi teoritikal meliputi kesalahan siswa dalam menjelaskan fakta-fakta mengenai beberapa bangun (sulit membedakan jenis-jenis segitiga berdasarkan sisi dan sudut) dan kesalahan dalam memahami beberapa rumus/ formula (bahwa rumus volume prisma, kubus, balok, tabung sebenarnya sama).

Miskonsepsi yang terjadi, menjadi penghalang siswa dalam memahami sebuah materi, padahal hal tersebut merupakan sesuatu yang penting dalam proses pembelajaran, terlebih dalam matematika, karena matematika mempunyai sifat saling terkait antara materi sebelumnya dengan materi yang akan datang. Ketika siswa belajar hal yang baru maka pengetahuan mereka sebelumnya (yang mengalami miskonsepsi) akan digunakan, dan siswa akan terus menolak perubahan-perubahan yang baru mereka temui. Sehingga miskonsepsi yang terjadi menciptakan hambatan ketika siswa belajar matematika dan menuntun seseorang pada kesalahan yang terus menerus (Dayanti \& Nursangaji, 2019). Berdasarkan hal tersebut, prestasi siswa dalam belajar matematika menjadi buruk dan pembelajaran menjadi tidak bermakna bagi siswa (Mohyuddin \& Khalil, 2016).

Kajian ini dipandang penting untuk dianalisis, apakah miskonsepsi yang terjadi bersumber dari guru, siswa itu sendiri atau bahkan buku ajar. Miskonsepsi yang bersumber dari siswa adalah kesalahan siswa yang berasal dari konsep awal yang dikuasai siswa sebelum proses pembelajaran berlangsung tentang konsep tertentu. Hal ini dapat terjadi karena adanya ketidaksesuaian konsep awal yang dimiliki siswa dengan konsep yang sebenarnya. Miskonsepsi yang datang dari guru terjadi ketika kurangnya penguasaan konsep yang dimiliki oleh guru terhadap konsep tertentu, sehingga ketika penyampaian konsep kepada siswa menjadi tidak sesuai. Pada dasarnya, siswa pasti menganggap bahwa semua yang disampaikan oleh guru adalah benar, namun jika guru menyampaikan konsep yang kurang tepat, maka ini akan berdampak buruk terhadap pembentukan konsep siswa. Miskonsepsi juga dapat disebabkan oleh buku ajar. Kesalahan dari buku ajar biasanya dalam penyusunannya, misalnya penjelasan yang keliru, hanya berisi penyampaian rumus secara langsung (membuat siswa hanya hapal namun tidak memahaminya) atau penyajian contoh soal yang tidak sesuai konten.

Miskonsepsi yang terjadi pada siswa sangat sulit untuk diubah/diperbaiki, karena setiap orang membangun pengetahuan atas dasar pengalamannya (Fitriani et.al, 2018; Skemp, 2012), jika seseorang telah membangun sebuah pengetahuan, maka ia akan sulit untuk diberi tahu bahwa hal tersebut salah apalagi memintanya untuk mengubah konsepsi tersebut. Oleh karena itu, ada kebutuhan untuk mengidentifikasi miskonsepsi, juga bertanggung jawab untuk memperbaikinya. 
Berdasarkan permasalahan yang telah diuraikan, maka pertanyaan penelitian dalam penelitian ini yaitu:

1. Jenis miskonsepsi apa yang terjadi pada siswa dalam mempelajari konsep geometri?

2. Sejauh mana level geometri siswa yang mengalami miskonsepsi?

\section{METODE PENELITIAN}

Jenis penelitian dalam penelitian ini adalah penelitian deskriptif kualitatif. Penelitian kualitatif ini sering juga disebut metode penelitian naturalistik, karena penelitiannya dilakukan pada kondisi yang alamiah (natural setting). Sampel dalam penelitian ini adalah siswa SMP kelas 9 sebanyak 30 orang. Fokus penelitian ini adalah mendeskripsikan miskonsepsi yang terjadi pada siswa dalam mempelajari konsep-konsep geometri pada sekolah menengah pertama (segitiga, segiempat, bangun ruang sisi datar dan lengkung) dan faktor penyebab terjadinya hal tersebut pada siswa SMP. Instrumen yang digunakan adalah soal tes diagnostik mengenai segitiga, segiempat, bangun ruang sisi datar dan lengkung, tes geometri Van Hiele, lembar wawancara dan buku ajar. Teknik pengumpulan datanya adalah pertama tes diagnostik diberikan kepada siswa, kemudian melakukan wawancara kepada siswa yang terpilih (siswa yang mengalami miskonsepsi), menelaah buku ajar yang digunakan oleh siswa dalam belajar dan menelaah level geometri siswa untuk siswa (terlebih yang mengalami miskonsepsi).

Penelitian kualitatif menghasilkan kebenaran yang bersifat objektif, karena itu keabsahan data merupakan hal yang sangat penting. Keabsahan data yang diperoleh dalam penelitian dilakukan melalui triangulasi data. Triangulasi yang digunakan adalah membandingkan hasil analisis data dari subjek satu dengan subjek lainnya. Analisis data yang dilakukan melalui teknik analisis kualitatif deskriptif untuk memperoleh gambaran umum dan menyeluruh tentang situasi yang sedang diteliti. Teknik analisisnya terdiri dari reduksi data, penyajian data, dan kemudian ditelaah sehingga menghasilkan suatu kesimpulan yang berarti.

\section{HASIL DAN PEMBAHASAN}

Tes diagnosis yang diberikan kepada 30 orang siswa berjumlah 6 soal. Dari 30 orang siswa yang mengerjakan, terdapat 5 orang siswa yang mengalami miskonsepsi dengan letak kesalahan yang serupa. Selanjutnya, 5 orang tersebut dianalisis lebih lanjut untuk mengetahui jenis-jenis kesalahannya disajikan berikut.

Tabel 1.

Jenis-jenis miskonsepsi yang dialami siswa dalam mengerjakan soal geometri

\begin{tabular}{lll}
\hline \multicolumn{1}{c}{$\begin{array}{c}\text { Jenis-jenis } \\
\text { miskonsepsi }\end{array}$} & & \\
\hline Miskonsepsi & - & Kesalahan dalam menentukan tinggi pada segitiga \\
Klasifikasional & - & Kesalahan dalam menentukan tinggi pada jajargenjang \\
& - & Keliru menentukan diagonal bidang dan bidang diagonal pada kubus \\
Miskonsepsi & - & Kesalahan dalam menentukan hubungan antara bangun-bangun segiempat \\
Korelasional & - & Kesalahan dalam menentukan hubungan antara konsep prisma dengan konsep kubus, \\
& & balok, maupun tabung \\
Miskonsepsi & - & Kesalahan dalam menentukan hubungan antara konsep limas dengan konsep kerucut \\
Teoritikal & - & Kesalahan siswa dalam mengklasifikasikan jenis-jenis segitiga \\
& - & Kesalahan dalam menentukan rumus luas permukaan dan volume pada limas \\
& - & Kesalahan dalam memahami beberapa rumus/ formula (bahwa rumus volume prisma, \\
\end{tabular}

Berdasarkan analisis pada Tabel 1 yaitu mengenai jenis-jenis miskonsepsi yang dialami siswa dalam mengerjakan soal geometri, selanjutnya akan ditelaah penyebab terjadinya miskonsepsi tersebut yang disajikan pada Tabel 2. 
Tabel 2.

Penyebab terjadinya miskonsepsi pada konsep geometri

\begin{tabular}{|c|c|}
\hline Miskonsepsi siswa & Penyebab terjadinya miskonspsi \\
\hline Kesalahan dalam menentukan tinggi pada segitiga & - Siswa tidak mengetahui definisi tinggi \\
\hline Kesalahan dalam menentukan tinggi pada jajargenjang & - Siswa tidak mengetahui definisi tinggi \\
\hline $\begin{array}{l}\text { Tertukar antara diagonal bidang dan bidang diagonal } \\
\text { pada bangun ruang sisi datar }\end{array}$ & $\begin{array}{l}\text { - Siswa memiliki kemampuan spasial yang rendah } \\
\text { - Siswa hanya menghafalkan konsep }\end{array}$ \\
\hline $\begin{array}{l}\text { Kesalahan dalam menentukan hubungan antara bangun- } \\
\text { bangun segiempat } \\
\text { Kesalahan dalam menentukan hubungan antara konsep } \\
\text { prisma dengan konsep kubus, balok, maupun tabung }\end{array}$ & $\begin{array}{l}\text { - Siswa tidak memahami definisi-definisi dari bangun } \\
\text { segiempat secara komprehensif } \\
\text { - Siswa tidak memahami sifat-sifat yang terdapat } \\
\text { pada bangun ruang, sehingga mereka tidak bisa } \\
\text { mendefinisikan bangun ruang secara komprehensif } \\
\text { - Siswa hanya menghafal }\end{array}$ \\
\hline $\begin{array}{l}\text { Kesalahan dalam menentukan hubungan antara konsep } \\
\text { limas dengan konsep kerucut }\end{array}$ & $\begin{array}{l}\text { - Siswa tidak memahami sifat-sifat yang terdapat } \\
\text { pada bangun ruang, sehingga mereka tidak bisa } \\
\text { mendefinisikan bangun ruang secara komprehensif } \\
\text { - Siswa hanya menghafal }\end{array}$ \\
\hline $\begin{array}{l}\text { Kesalahan siswa dalam membedakan jenis-jenis segitiga } \\
\text { berdasarkan sisi dan sudut }\end{array}$ & $\begin{array}{l}\text { - Sudut pandang siswa mempelajari segitiga belum } \\
\text { komprehensif }\end{array}$ \\
\hline $\begin{array}{l}\text { Kesalahan dalam menentukan rumus luas dan volume } \\
\text { pada limas } \\
\text { Kesalahan dalam mengidentifikasi limas dan prisma }\end{array}$ & $\begin{array}{l}\text { - Siswa bingung menggunakan rumus luas dan } \\
\text { volume } \\
\text { - } \quad \text { Siswa hanya menghafalkan konsep } \\
\text { - } \quad \text { Kemampuan spasial siswa rendah }\end{array}$ \\
\hline $\begin{array}{l}\text { Kesalahan dalam memahami beberapa rumus/ formula } \\
\text { (bahwa rumus volume prisma, kubus, balok, tabung } \\
\text { sebenarnya sama). }\end{array}$ & - Siswa hanya menghafalkan rumus \\
\hline
\end{tabular}

Setelah ditelaah, terdapat beberapa jenis miskonsepsi yang terjadi pada siswa seperti tertuang pada Tabel 2, tabel tersebut menguraikan beberapa jenis miskonsepsi yang terjadi pada siswa dalam mempelajari beberapa konsep geometri di sekolah menengah pertama. Berdasarkan hasil kajian yang mendalam, pada tabel tersebut diuraikan beberapa hal yang menjadi penyebab terjadinya miskonsepsi kepada siswa. Berikut salah satu hasil pekerjaan siswa yang mengalami miskonsepsi.

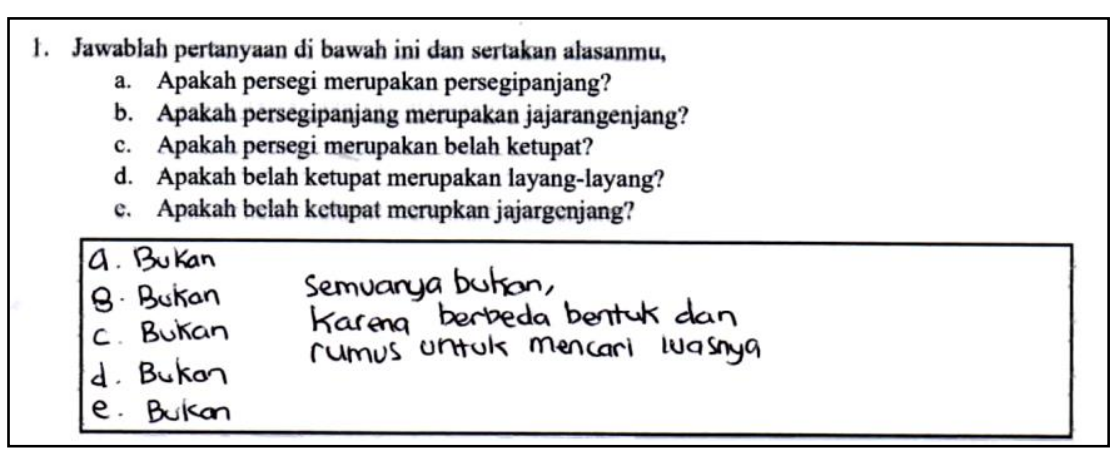

\section{Gambar 1. Hasil jawaban siswa yang mengalami miskonsepsi korelasional}

Berdasarkan Gambar 1 bahwa terdapat beberapa jenis miskonsepsi, diantaranya siswa mengalami miskonsepsi korelasional. Siswa mengalami kesalahan dalam menentukan hubungan antara bangun-bangun segiempat, dari jawaban yang diberikan oleh siswa, terlihat siswa tidak mengetahui hubungan antara bangun datar tersebut. 
Kondisi tersebut terjadi karena siswa hanya melihat visualnya saja, tidak memahami sifat-sifat yang terkandung di dalamnya (Ozerem, 2012), sehingga mereka menganggap tidak ada hubungan antara bangun tersebut satu sama lain.

2. Perhatikan gambar jajargenjnag dan segitiga di bawah ini, dapatkah kamu menentukan luasnya?
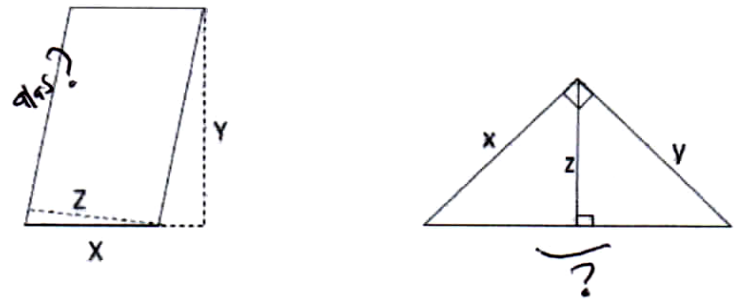

$$
\begin{array}{ll}
\text { Luas Jajarg'enjang }=a \times t, & \begin{array}{l}
\text { tidak bisa dicari, Kafena } \\
\text { alashya tidak diketahul }
\end{array} \\
\text { Luas } \Delta=\frac{1}{2} a \times t, & \text { tingginya tidak diketahui }
\end{array}
$$

\section{Gambar 2. Hasil jawaban siswa yang mengalami miskonsepsi klasifikasional}

Selanjutnya, siswa mengalami miskonsepsi jenis lain, seperti hasil kerja yang tertuang pada Gambar 2, yaitu siswa mengalami miskonsepsi klasifikasional. Siswa tidak mampu menentukan tinggi dari segitiga ataupun jajargenjang, hanya karena gambar yang disajikan pada soal tidak biasa, siswa terbiasa melihat gambar-gambar yang lebih bersifat umum dan terlihat tinggi dari bangun tersebut. Hal ini terjadi karena siswa tidak mengetahui definisi dari tinggi, sehingga siswa kebingungan menentukan tinggi dan berdampak kepada ketidakmampuan siswa dalam menentukan luas dari dua bangun tersebut.

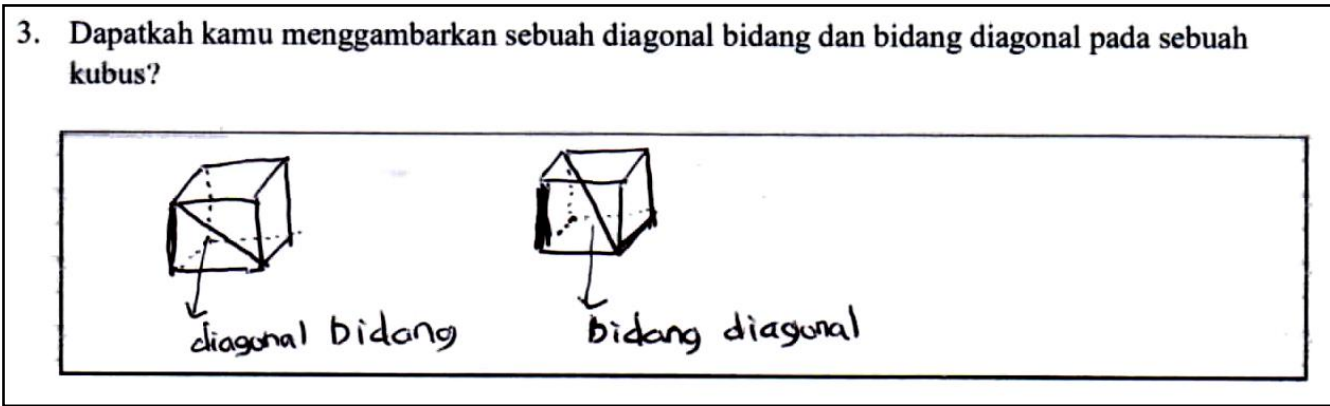

Gambar 3. Hasil jawaban siswa yang mengalami miskonsepsi klasifikasional

Siswa kembali mengalami miskonsepsi klasifikasional seperti pada Gambar 3. Siswa memiliki kemampuan spasial yang cenderung rendah, sehingga kesulitan melihat tilik ruang sebuah bangun ruang, selain itu juga siswa hanya menghafalkan konsep dari diagonal bidang dan bidang diagonal tersebut tanpa memahaminya dan pada akhirnya siswa keliru merepresentasikannya (Fitriani et.al, 2017). 


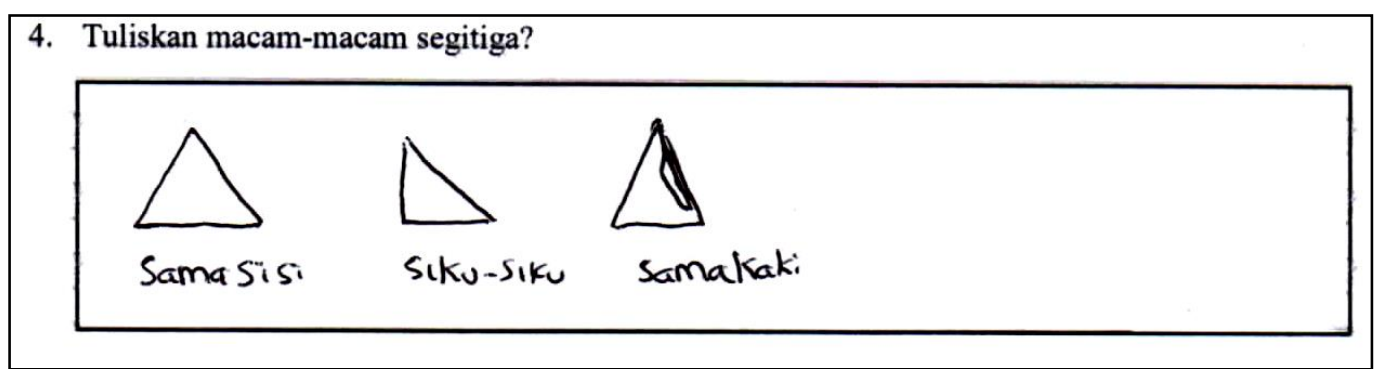

Gambar 4. Hasil jawaban siswa yang mengalami miskonsepsi teoritikal

Miskonsepsi jenis terakhir adalah miskonsepsi teoritikal, seperti pada Gambar 4 yang merupakan hasil pekerjaan siswa yang mengalami miskonsepsi jenis tersebut. Sebetulnya jawaban siswa tidak keliru hanya saja pemahaman siswa tidak lengkap, siswa kurang komprehensif dalam memahami jenis-jenis segitiga. Jawaban yang diharapkan adalah siswa dapat menjawab jenis-jenis segitiga berdasarkan sisi (segitiga sama sisi, segitiga siku-siku, segitiga sama kaki) dan berdasarkan sudut (segitiga lancip, segitiga tumpul, segitiga siku-siku), namun siswa hanya menjawab segitiga berdasarkan sisi saja.

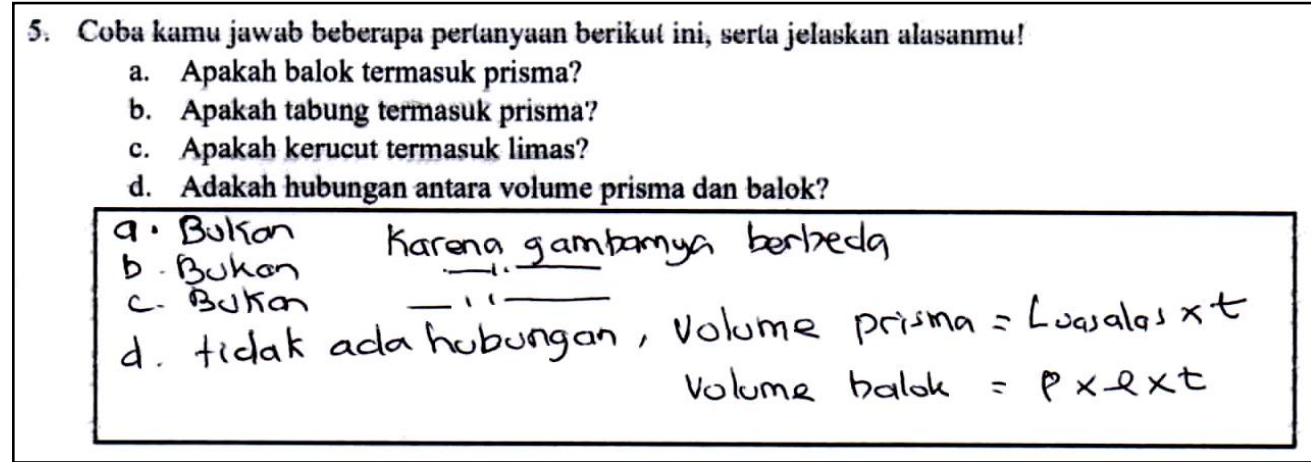

\section{Gambar 5. Hasil jawaban siswa yang mengalami miskonsepsi teoritikal}

Jenis miskonsepsi ini sebetulnya tidak terlalu keliru, namun tetap harus diperbaiki, contohnya seperti pada pekerjaan siswa yang tertuang pada Gambar 5, dimana hasil tersebut menunjukkan miskonsepsi yang dilakukan oleh siswa dan termasuk ke dalam miskonsepsi teoritikal. Dari jawaban tersebut terlihat siswa hanya menangkap informasi dari visualnya saja, siswa tidak memahami sifat-sifat yang terdapat pada bangun ruang, sehingga mereka tidak bisa mendefinisikan bangun ruang secara komprehensif. Siswa terlihat hanya menghafal rumus tanpa memaknai rumus tersebut bagaimana dihasilkan, sehingga memandang bahwa sebenarnya volume prisma dan balok memiliki prinsip yang berbeda.

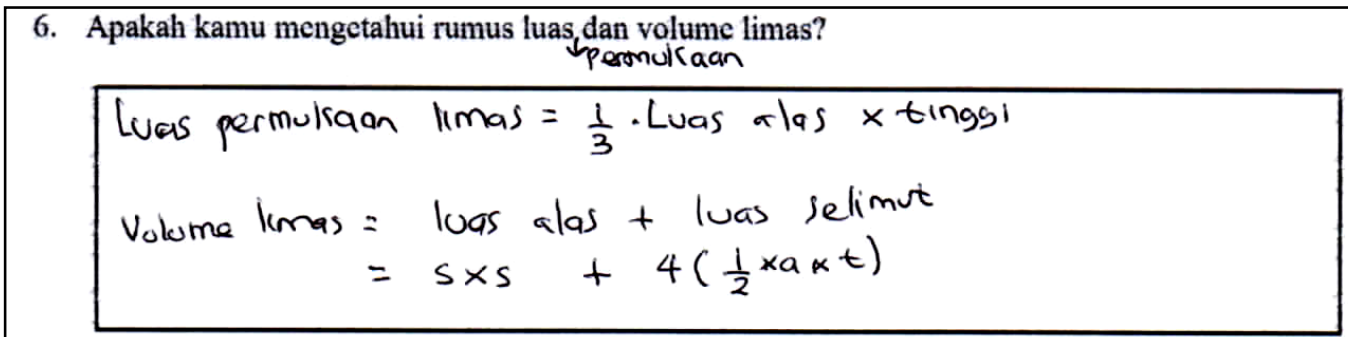

\section{Gambar 6. Hasil jawaban siswa yang mengalami miskonsepsi teoritikal}

Miskonsepi teoritikal paling sering dijumpai pada siswa, seperti Gambar 6 yang merupakan hasil pekerjaan siswa yang mengalami miskonsepsi jenis ini. Siswa tertukar ketika menentukan luas 
permukaan dan volume limas. Mungkin miskonsepsi ini tidak hanya terjadi pada konsep limas saja, bisa jadi hal ini terjadi juga untuk bangun ruang yang lain. Hal ini mungkin terjadi karena siswa hanya berorientasi kepada menghafal rumus luas permukaan dan volume dan mereka tidak memaknainya. Siswa juga mungkin kesulitan menghafal rumus-rumus tersebut, karena mereka berpikir bahwa volume-volume bangun ruang itu sangat banyak. Mereka tidak memahami bahwa sebenarnya rumus tersebut saling berkaitan dan merupakan turunan dari rumus yang serupa (misalnya rumus volume prisma itu sama dengan rumus volume kubus, balok, tabung).

Setelah dianalisis jenis-jenis miskonsepsi yang terjadi pada siswa, 5 orang siswa yang mengalami miskonsepsi selanjutnya ditelaah hasil tes geometri Van Hielenya. Dari hasil yang diperoleh, ke-5 siswa tersebut berada pada level 1 yaitu visualisasi. Pada level ini, anak mengenal suatu bentuk geometri dengan memperhatikan bangun secara visual saja tanpa mengetahui sifatsifat bangun tersebut. Pada level ini mereka belum menyadari adanya sifat-sifat dari bentuk geometri tersebut (Hendriana \& Fitriani, 2019). Berdasarkan analisis ini, miskonsepsi mungkin terjadi karena siswa masih ada pada level 1 (visualisasi) pada level berpikir Van Hiele. Atas analisis yang dilakukan, sebaiknya pemahaman awal mengenai konsep-konsep yang mendukung konsep tersebut harus lebih dikuatkan kepada siswa, sehingga miskonsepsi yang sering terjadi pada siswa khususnya dalam mempelajari materi geometri sekolah menengah ini dapat terminimalisir dan juga level berpikir Van Hiele siswa sebaiknya harus dikembangkan.

Berdasarkan hasil obeservasi yang dilakukan terhadap beberapa jenis buku ajar yang digunakan, terdapat beberapa temuan yang diduga dapat menjadi penyebab terjadinya miskonsepsi, diantaranya adalah: (1) penulisan rumus tidak disertai dengan bagaimana cara memperolehnya; (2) penjelasan mengenai unsur-unsur pada bangun ruang tidak disertai contoh; (3) sistematika penyampaian materi ada yang tidak terstruktur; (4) tidak pernah mengaitkan antara beberapa bangun datar maupun bangun ruang. Temuan ini sejalan dengan penelitian yang telah dilakukan oleh beberapa peneliti sebelumnya (Ainiyah, 2016). Berdasarkan uraian tersebut, miskonsepsi juga akan terhindarkan dari siswa, jika siswa memiliki motivasi yang baik terhadap pembelajaran matematika (Eftafiyana et.al, 2018).

\section{KESIMPULAN}

Setelah seluruh data dianalisis terdapat beberapa kesimpulan sesuai dengan pertanyaan penelitian yang telah dikemukakan, yaitu: (1) setelah siswa diberikan tes diagnostik, terdapat lima orang siswa yang mengalami miskonsepsi. Miskonsepsi yang dihasilkan yaitu miskonsepsi klasifikasional, miskonsepsi korelasional dan miskonsepsi teoritikal; (2) setelah mengetahui jenisjenis miskonsepsi yang diterjadi pada siswa, selanjutnya dianalisis level kemampuan geometrinya berdasarkan level geometri Van Hiele. Lima orang siswa mengalami miskonsepsi dan mereka berada pada level 1 berdasarkan level geometri Van Hiele. Kesimpulan yang diperoleh, bahwa siswa yang mengalami miskonsepsi merupakan siswa yang level geometri Van Hielenya berada di bawah.

\section{REKOMENDASI}

Agar miskonsepsi tidak berulang untuk siswa lainnya, maka harus diperhatikan beberapa hal, diantaranya adalah apersepsi mengenai materi-materi prasyarat yang harus dikuasai sebelum mempelajari materi-materi ini seperti yang telah tertuang dalam artikel ini. Selain itu, cara menyampaikan konsep kepada siswa juga harus terkonstruksi secara benar, hindari pemberian konsep secara langsung dan menekankan pada hanya sekedar hafalan.

\section{UCAPAN TERIMA KASIH}

Kami ucapkan terima kasih kepada Direktorat Pembelajaran dan Kemahasiswaan Kemenristekdikti atas hibah yang diberikan dalam program Penugasan Dosen di Sekolah (PDS), berkat hibah tersebut penelitian ini dapat terlaksana dengan baik hingga dapat menghasilkan luaran artikel ini. 


\section{DAFTAR PUSTAKA}

Ainiyah, L. A. (2016). Identifikasi miskonsepsi siswa dalam materi geometri pada pembelajaran matematika siswa kelas vii smp negeri 1 punggelan. Journal Student UNY, (3).

Ay, Y. (2017). A review of research on the misconception in mathematics education. Education Research Highlights in Mathematics, Science and Technology, 21-31.

Dayanti, P., \& Nursangaji, A. (2019). Miskonsepsi siswa dikaji dari gaya kognitif dalam materi jajargenjang di sekolah menengah pertama. Jurnal Pendidikan dan Pembelajaran Khatulistiwa, $8(9), 1-9$.

Eftafiyana, S., Nurjanah, S. A., Armania, M., Sugandi, A. I., \& Fitriani, N. (2018). Hubungan antara kemampuan berpikir kreatif matematis dan motivasi belajar siswa smp yang menggunakan pendekatan creative problem solving. Jurnal Teorema: Teori dan Riset Matematika, 2(2), 8592.

Fitriani, D. A., Mardiyana, \& Pramesti, G. (2017). Analisis miskonsepsi siswa pada pembelajaran matematika materi pokok ruang dimensi tiga ditinjau dari kecerdasan visual-spasial siswa kelas x sma negeri 1 klaten tahun ajaran 2012/2013. Jurnal Pendidikan Matematika dan Matematika (JPMM), 1(6), 27-34.

Fitriani, N., Suryadi, D., \& Darhim. (2018). Analysis of mathematical abstraction on concept of a three dimensional figure with curved surfaces of junior high school students analysis of mathematical abstraction on concept of a three dimensional figure with curved surfaces of junior high school student. Journal of Physics: Conf. Series, 1132(012037), 1-7.

Hendriana, H., \& Fitriani, N. (2019). Mathematical abstraction of year 9 students using realistic mathematics education based on the van hiele levels of geometry. Jurnal Didaktik Matematika, 6(2007), 1-11.

Kusuma, D. A. (2019). Peningkatan komunikasi matematis siswa menggunakan pembelajaran kontekstual berbasis etnomatematika dengan penerapan mozart effect (studi eksperimen terhadap siswa sekolah menengah pertama). Jurnal Teorema: Teori dan Riset Matematika, $4(1), 65-74$.

Mohyuddin, R. G., \& Khalil, U. (2016). Misconceptions of students in learning mathematics at primary level. Bulletin of Education and Research, 38(1), 133-162.

Ozerem, A. (2012). Misconception in geometry and suggested solution for seventh grade students. International Journal of New Trends in Arts, Sports \& Science Education, 1(4), 23-35.

Skemp, R. R. (2012). The psychology of learning mathematics: expanded american edition. New York: Routledge. 